\title{
Students' Needs for Academic Writing at the English Education Department
}

\author{
Nur Fatimah \\ English Education Department of Universitas Ahmad Dahlan, Yogyakarta, Indonesia \\ nur.fatimah@pbi.uad.ac.id
}

\begin{abstract}
There are some demand and facts on English teching and learning that made the research conducted. They are the teaching and learning in the academic writing class, the feedback from lecturers on the students language performance, the students' weaknesses in writing, the students' expectation for the materials, and the requirement on publishing scientific articles. The study, then, reveals the students' needs for academic writing at the English Education Department of Ahmad Dahlan University and their problems in academic writing. The aspects investigated were teaching materials, learning activities, skills and learning resources. The data were obtained by a questionnaire to describe whether the stated items very interesting/very important - not very interesting/not very important. The number of population is 370 . Krejcie and Morgan table was referred for the sample. An open question was responded to enable respondents to share more feedback on their academic writing skills and problems. The results show that the materials designed by the Department are worth to teach. Further, interesting learning activities include getting feedback from the lecturer and peers, and in-class writing practice. In relation to writing, the students confirm the importance of essay elements and academic work, outlining, paraphrasing and producing complete academic writing. Another finding is priority to use textbooks, references from the internet and journals. The last is that the students have problems in developing ideas, grammar, vocabulary, and language expressions.
\end{abstract}

Keywords: needs analysis, academic writing, materials, academic writing problems

How to Cite: Fatimah, N. (2018). Students' needs for academic writing at the English education department. English Language Teaching Educational Journal, 1(3), 161-175.

\section{INTRODUCTION}

The development of education is influenced by not only external but also internal factors. Policy from the government as well as regulations from instutions affect the output of the educational process. The Decree of Director General of Higher Education No. 152 / E / T / 2012 requires the obligation of scientific publication for graduates of $S 1 / S 2 / S 3$ (undergraduate, master and doctoral degrees). Thus, the process undertaken by students in the Academic Writing class influences the success of students in obtaining scientific writing skills.

English Education Department as one of the related parties takes significant roles in empowering the Indonesian people in particular young generations taking English as their major. What emerges in the society may reflect what happened in classroom settings. Ability to express ideas, feelings and experiences through words can be traced back to the process of teaching 
and learning. Accordingly, the demand to increase the number of scientific writing publication can be associated with the process of learning writing.

In fact, class observations and preliminary interviews with some students and lecturers conducted by the researcher showed that the 5th semester students and above, who took the Academic Writing course, have difficulty writing scientific papers. Some lecturers of Seminar on Language Teaching and thesis supervisors acknowledge student weaknesses in written expression in the form of papers or student thesis.

The question that arises is whether the materials delivered have supported each other for the success of students in completing their study, including writing their thesis? What are exactly their wants, interests, and abilities related to scientific writing skills? What activities are experienced by students in the learning process of Academic Writing?

Academic Writing learning is still implemented traditionally. The lecturer delivered the material classically, students listened, worked on the Acacemic Writing exercise and submitted their writing. So far, there has been no specific guide for the Academic Writing class, so that the main material comes from lecturer presentation and parts of the book as the references.

Before getting into the teaching material, it becomes important to analyze the needs of Academic Writing students. This paper aims to describe the research result on the needs of the English Education Department (EED) students for Academic Writing.

\section{Academic Writing}

Writing activity takes into account the role of the writer, the content, the reader and the form of language that is commonly used (Taylor, 2009). In an academic writing, a writer is required to provide reasons that reinforce the ideas conveyed. All is delivered by the author with clear and acceptable language for the academic community.

When composing academic writing, the writer has to consider the followings. Academic writing contains a structured, formal and objective pattern, and the language used is often abstract and complex. The term Academic Writing is related to writing to fulfill academic assignments or assignments as teachers and researchers do for publication and conference purposes attended by academics (Thais and Zawachi (2006), Paquot (2010), Taylor , (2009), Bailey (2003)).

Hedge (in Murray and Christison (2011)) states five competencies that must be achieved in Academic Writing. First, students are able to have a high level of organizational competence so that the ideas in their writing are clearly understandable. Next, students also have high accuracy in writing by paying attention to technical terms to avoid misunderstanding in their meaning. Third, students as writers need to control the use of grammar so that information is conveyed. Furthermore, the author must know the vocabulary in the discipline 
and then students as writers must be able to integrate all these competencies to produce a style that is suitable for the reader and certain context.

Writing errors especially in second language learning can arise due to several factors. According to Myles (2002) there are social and cognitive factors. Social factors include such as negative attitudes toward English, insignificant progress in mastering the language learned, a large social and psychological barrier between learners and the culture of the speakers of the language being studied and lack of motivation in learning.

Different from social factors, the cause of errors in writing can come from cognitive factors. For example, the acquisition of scientific vocabulary and the style used, the writing process (construction, transformation and execution of ideas, according to Anderson (1985) in Myles (2002) which is undertaken at the same time students also think about how to realize their ideas in writing. various knowledge in writing, for example relating to discourse, readers, rules related to sociolinguistics, the influence of language used (L1).

Academic Writing in the English Education Department is a compulsory subject offered in semester five. The competency expected by students is their ability to write scientific papers in English.

Academic Writing courses ideally include materials that make the students able to write scientific work. The materials should be made gradually from developing ideas from general to specific, thesis statements and supporting details, parts of scientific writing, outlining to writing some types of writing that are often found in scientific work presentations, such as descriptive, comparison and contrast and argumentative. In addition to these materials, subjects such as paraphrasing, making conclusions and making reference lists are topics discussed in the Academic Writing class.

To arrive at a conducive learning process and the satisfying products of Academic Writing, the provision of teaching materials that support the achievement of these goals is certainly of importance. However, in order to produce good materials, the first attempt that needs to be made is to get data about the needs of the students related to the subject being studied.

\section{Needs Analysis}

Brown defines needs analysis as systematic data collection and analysis of all relevant information needed to meet learners' needs. According to Brown (1995) needs analysis is

"...the systematic collection and analysis of all relevant information necessary to satisfy the language learning requirements of students within the context of the particular institutions involved in the learning situation."

The need analysis, as stated by Murray and Christison (2011), is expected to be able to answer questions: What are students already aware of and can do? What do they need to know and what they can do? Furthermore, both of them explained the need for exploration of data regarding the identity, experience and goals of students in learning the subjects presented (Murray and Christison, 2011). 
Need analysis according to Hutchinson \&Waters (1991) includes target needs and learning needs. Target needs focus on the needs of students in certain situations including needs (necessities), wants (wants) and weaknesses (lacks) while learning needs focus on what they need to be able to learn. Why students need Academic Writing, what they want in the class and what problems or difficulties they feel or experience related to Academic Writing.

Scientific or academic writing can be highlighted from 4 parts. According to Bailey (2003), scientific writing can be directed at the writing process, the accuracy in writing, the important elements in writing and the availability of examples in producing writing. These four sections can be seen by looking at the following issues. Do students have difficulties on the basic knowledge of writing, reading and recording for scientific writing and writing following the stages in writing, including determining planning, organizing, compiling scientific work? Do students recognize and can they use the types of written text (comparison, cause and effect, definitions, etc.), styles in scientific writing, visual information, etc? Or is there an aspect of grammar that is a problem or is considered difficult by most students in composing Academic Writing?

Meanwhile, what is trying to be explored related to learning needs is the need for the learning process. Tomlinson (1998) states that the needs of students include personal needs, learning needs and future professional needs.

Considering the current needs in learning English, utilizing technology can be a significant point. Academic Writing can be supported by the use of learning media. Nowadays, information and communication technology is becoming a trend regarding their many benefits in learning.

Ybarra and Green (2003) state that the use of technology can facilitate verbal interaction, develop vocabulary, improve reading and writing skills. Utilization of information and communication technology-based technologies such as computers according to Mills (2006) in Nurohman (2011) enables to achieve the form of "complex skills" needed in the global era while also allowing student-centered learning.

Further, Alvarez (2007) conducted a qualitative study of the difficulties of students in research writing. The results show that ESL learners still need help from their instructors in completing research writing assignments; that they need clear, explicit commands about tasks to do, and that individual guidance is important in lecturer communication during the learning process.

Technology with many features can also help teachers/lecturers to develop materials. Dudeney and Hockly (2007) explain various technologies for teaching English. The types range from word processors, website utilization, e-mail, online reference tools, technology-based materials, elearning etc. The selection of the right technology will greatly help convey the teaching materials to make them easier for students to reach the targeted objectives through the learning process. 


\section{RESEARCH METHOD}

This research is exploratory and descriptive. Questionnaire of needs analysis was modified from the questionnaire used in previous research exploring the needs of students in the CLTPD-Children Language Teaching Program Development course (Fatimah, 2012). The materials listed were adjusted for those of Academic Writing. The questionnaire for this research covers the target needs and learning needs of Academic Writing students. The questionnaire was consulted with an expert in English teaching.

The questionnaire of this study consists of 3 parts. The initial section lists the materials in the Academic Writing. Respondents were asked to select which materials were to maintain and which to discard. There was enough space for the students to describe their reason(s) for their answer(s), if necessary. Next, several groups of questions are presented to determine the needs of Academic Writing students. The aspects included in the questionnaire are: learning activities, skills in Academic Writing, and learning sources.

Table 1. Blue Print of the Questionnaire of Academic Writing Needs

\begin{tabular}{llr}
\hline No. & \multicolumn{1}{c}{ Aspects } & Number of Items \\
\hline 1 & Learning activities & 10 \\
2 & Skills & 12 \\
3 & Learning sources & 6 \\
\hline
\end{tabular}

Respondents also had the opportunity to express their suggestions and problems in Academic Writing. In addition, the researcher also obtained the data from the interview with 2 seminar lecturers and 2 thesis supervisors.

The population for data collection was students of English Education Department of the Faculty of Teacher Training and Education, Ahmad Dahlan University $(\mathrm{N}=370)$. The sample was determined by a purposive technique. Only the students of the Academic Writing classes filled out the questionnaire. The filling and return rate of the questionnaire was $73.82 \%$.

\section{FINDINGS AND DISCUSSION}

\section{Students' Needs in Academic Writing}

The students as the respondents were asked about the list of Academic Writing materials in the English Education Department (EED). The results showed that they confirmed the themes listed. The students considered the importance of these themes to be taught ( mean $=0.877$ ).

Table 2. Needs on Academic Writing Materials

\begin{tabular}{ll}
\hline Material & Mean \\
\hline a. Conclusion & 0.943 \\
b. Writing references & 0.943 \\
c. Argumentative writing & 0.908 \\
d. Introduction & 0.894
\end{tabular}




\begin{tabular}{|c|c|}
\hline Material & Mean \\
\hline e. Expository writing & 0.887 \\
\hline f. Discussion of students' work & 0.879 \\
\hline g. Direct and indirect quotation & 0.872 \\
\hline h. Review of organization of essays and outlining & 0.858 \\
\hline i. Descriptive writing & 0.851 \\
\hline j. $\quad$ Drafting & 0.738 \\
\hline
\end{tabular}

Materials on review of organization of essays and outlining, descriptive writing and drafting are at the lowest means.

Some of the reasons that appear in the questionnaire filled by Student 1 are as the following

in my opinion, the type of text most easily understood by students is Descriptive Text. Most English Education students who study Academic Writing courses are able to make Descriptive Text. Although descriptive text taught is more extensive than when students have studied in junior and senior high schoos, in my opinion, giving such a material is less effective ...

While for drafting, the reason informed by students is that $\mathrm{j}$ (drafting) should be eliminated because it already exists in the other material ..." and other respondents stated, "... the material of Review of Organization essays and outlining is not needed.

Furthermore, related to lecturing activities, the results of the study are presented at Table 3 .

Table 3. Needs on Learning Activities

\begin{tabular}{ll}
\hline Learning Activities & Mean \\
\hline a. getting feedback or suggestions from the & 4.518 \\
b. getting feedback or suggestions from friends & 4.142 \\
c. practice writing directly in class & 4.028 \\
d. individual work & 3.979 \\
e. class discussion & 3.858 \\
f. working in pairs & 3.830 \\
g. elearning for writing & 3.660 \\
h. material presentation by students & 3.404
\end{tabular}




\begin{tabular}{lll}
\hline \multicolumn{2}{c}{ Learning Activities } & Mean \\
\hline i. & working in groups & 3.305 \\
j. & lecturing & 2.511 \\
\hline
\end{tabular}

Table 3 shows that there are 3 most interesting activities according to students. The activity is getting feedback from the lecturer and students (mean 4.518 and 4.142 respectively) and direct writing practice in class ( mean 4.028). Meanwhile, the opposite is the activity of lecturing, group work and the presentation of material by students (mean respectively 2.511 ; 3.305; and 3.404).

For skills that need to be mastered related to Academic Writing, the results findings are as reflected in Table 4.

Table 4. Needs on Skills in Academic Writing

\begin{tabular}{ll}
\hline \multicolumn{1}{c}{ Skills } & Mean \\
\hline a. $\quad$ Get to know essay parts and scientific works (intro, & \\
content, closing parts) & 4,688 \\
b. Make an outline & 4.411 \\
c. Make paraphrases (writing ideas from the theory in & \\
their own words) & 4.319 \\
d. Make a complete scientific article (paper) & 4.170 \\
e. Formulate a statement thesis & 4.135 \\
f. Make a quote (direct and indirect) & 4.128 \\
g. Make abstract scientific articles & 4.121 \\
h. Make a reference list & 4.113 \\
i. Make a summary & 4.078 \\
j. Make a full article & 4.043 \\
k. Draft & 3.979 \\
l. Revise the draft & 3.695 \\
\hline
\end{tabular}

Table 4 shows that recognizing essays and scientific works - intro, content, closing parts (mean 4.688), making outlines (mean 4.411) and making paraphrase ( mean 4.319) are three skills that are considered most important in Academic Writing. It also appears that the activities of revising and drafting and making full articles are inversely proportional to the 3 activities mentioned earlier.

Regarding material sources, EED students show their needs as presented in Table 5. 
Table 5. Learning Sources of Academic Writing

\begin{tabular}{lll}
\hline Learning Sources & Mean \\
\hline a. & Module / textbook & 4.511 \\
b. & Source from the Internet & 4.397 \\
c. & Journal articles & 4.234 \\
d. & Student worksheet & 3.936 \\
e. & Video & 3.688 \\
f. & Audio source & 3.468 \\
\hline
\end{tabular}

Students still consider the importance of the existence of modules / textbooks (mean $=4.511)$, sources from the Internet $($ mean $=4.397)$ and articles in scientific journals (mean $=4.234$ ). For sources derived from worksheets, videos and audio sources, students do not make them the most important source.

In accordance with Hutchinson and Waters (1991), the needs of students are also connected with weaknesses, obstacles or problems according to students.

\section{Students' Problems in Academic Writing}

According to EED students there are several problems in learning Academic Writing. The problems encountered can be mapped as follows.

Table 6. Problems in Academic Writing

\begin{tabular}{ll}
\hline \multicolumn{1}{c}{ Problems } & Percentage \\
\hline a. Developing ideas & 46.67 \\
b. Grammar & 16.67 \\
c. Motivation & 10 \\
d. Vocabulary and language expressions & 10 \\
e. Preparing references & 6.67 \\
f. Learning activities & 6.67 \\
g. Abstract writing & 3.33 \\
\hline
\end{tabular}

For Academic Writing, the main problem for EED students is developing ideas $(46.67 \%)$. This problem is followed by grammar $(16.67 \%)$, motivation and use of vocabulary and language expressions in academic writing (10\% each). These results show similarities with those of the interview with two seminar lecturers and two thesis supervisors at EED of Ahmad Dahlan University. The students have the problem on the flow of ideas in their academic writing, of producing grammatically correct sentences and of using words/registers and language expressions in their writing work.

In terms of grammar, the results of this study are different from those of other research findings by Luong Quynh Trang and Nguyen Thi Mai Hoa 
(2008). They showed that students in writing academic essays did not pay much attention to grammatical and spelling mistakes, they had various strategies to solve their difficulties.

In contrast to argumentative writing, from the results of the research conducted, the study reveals that the material discussed in the previous semester such as descriptive writing in EED, the students thought that should not be included in Academic Writing. Another reason according to students is that there is material that can be united with other materials. For example, expository writing can be combined with argumentative writing, another reason according is to save time.

Something similar was also found in the material about essay writing material review. Interestingly, when responding to questionnaires about essay but related to the scientific work, EED students generally think this as an important skill.

Scientific works that generally have the possibility of being discussed in an academic forum have certain parts. One important part is abstract. It should be noted whether the contents of the scientific work are based on research results or on discussing a problem without conducting research. Other important aspects are keywords and preparation of a reference list.

Moreover, in terms of learning needs, data obtained from EED students show that lecturing activities in class, group work and material presentations by students are not included in the activities that are of interest or are considered important. This finding has similarities with the opinions of students regarding activities at the CLTPD class - Children Language Teaching Program Development which shows the uninteresting lecture and presentation activities by students (Fatimah, 2012). The reason given by the Academic Writing students is because when the presentation was made the students felt unsure about what their friend had delivered. Students need judgments from the lecturer who is as an expert in the class.

In the Academic Writing class students consider feedback as important . What they expected was feedback from lecturers (mean $=4.518)$ as well as from fellow students (mean $=4.142$ ). According to Hyland (2003) feedback can be in the form of written feedback from the teacher/lecturer, conference/presentation between teachers and writers, and importantly peer feedback - feedback given by classmates. The finding of the study confirms that feedback from both the lecturer and the classmates is needed by the EED students. However, referring to the means, the students expect the feedback more from the lecturer.

Giving feedback by lecturers is also considered important in research on students who study EAP (English for Academic Purposes) as done by Setiawan (2009). Since students are not interested in the presentation method by students, lecturers need to think of various ways to provide feedback. Raimes (2002) warns that not all aspects of writing need to be commented on or given suggestions, the right media must be chosen to respond to student writing and the type of response. 
In line with Raimes, Murray and Christison state several things to be considered by the instructor in giving feedback. According to both, the feedback, should be specific, can vary depending on the situation, based on the work of students who were previously and sincerely delivered (Murray and Christison, (2011)). The same feedback to students, as Murray and Christison say, will only cause giving feedback to be meaningless.

Special points in giving feedback can be determined by the lecturer by taking into account the situation and conditions in the Academic Writing class. More specifically, students find it easier to recognize what revisions they need to do. Ferris (2002) in Hyland (2003) grouped feedback into 5: genre-specific errors (type of text used), stigmatizing errors (errors related to the intended readers), comprehensibility errors (related to clarity of the content), frequent errors (a mistake that is often made when writing), student-identified errors (errors expected by students to get suggestions from lecturers). Clear communication about the five types of errors that might occur in the student's writing can be the basis for a lecturer in giving feedback on student scientific work.

It is expected that through feedback, students' writing skills can improve. Lecturers in giving feedback need to pay attention to the following:

ESL writing teachers misread student texts, are inconsistent in their reactions, make arbitrary corrections, write contradictory comments, provide vague prescriptions, impose abstract rules and standards, respond to fixed and final products, and rarely make content-specific comments or offer specific strategies for revising the texts. . . . The teachers overwhelmingly view themselves as language teachers rather than writing teachers.

Zamel (1985) in Hyland (2003)

From the quote, giving feedback by the lecturer should be consistent, responding to writing with clear comments, giving suggestions related to the contents of the writing, offering strategies to revise the writing to support improvements in student writing skills.

A variety of feedback can be used by lecturers in providing suggestions to improve the quality of student scientific writing. Hyland (2003) offered in the form of comments, rubrics, hints such as line number, types of mistakes, then students conducted self-editing strategies, comments using audio media so they could also train students' listening skills and feedback by utilizing technology/computers.

The practice of giving or getting feedback from classmates also needs attention. Based on the researcher's observation after teaching writing for more than 10 years, the point that was used as the focus of the peer feedback was more on the superficial aspect, for example, concerning suggestions to improve the use of grammar. The content aspect has not been touched much. 
Therefore, lecturers need to explain or formulate criteria that can guide Academic Writing students in criticizing content from scientific works written by their classmates. With the existence of these criteria, perceptions of Academic Writing students will have more or less in common so that the author can easily follow up to revise the work she or he made. Giving this kind of feedback can be combined with a conference writing activities so that the suggestions of the students in a class for the scientific work and they can be a lesson for other students in the Academic Writing class.

In addition, the practice of writing in class is another important activity in student assessment (mean $=4.028$ ). Learning Academic Writing is to achieve the goal of being able to write scientifically, not just knowing what and how to write it. Writing skills can be learned, not solely depending on one's talents.

There are several skills or abilities in Academic Writing that are important according to EED students. The skills are to know the parts of scientific work, make outlines, paraphrase and make complete scientific articles. In the introduction, students can also be reminded of the importance of the thesis statement in writing scientific papers. The statement of the thesis statement is in the form of a sentence or clause. For beginner writers, the thesis statement should be explicit in the introduction to Academic Writing.

It is also important to see that the fluency of students in writing scientific works cannot be separated from the availability of resources as references. Three important material sources according to EED students are modules / textbooks, sources from the Internet and scientific journals. So far there have been no books or modules specifically for Academic Writing at the EED. The source used is compilation and adaptation of material from various references, and still refers to SAP (Lecturing Preparation Unit).

Sources from the Internet need to be clearly informed in detail so that student time is not much consumed for exploration of material sources. Some websites that might be used as references in further studying Academic Writing material are https://owl.english.purdue.edu/owl/section/1/2/ http://owl.english.purdue.edu/owl/resource / 560/01 / and for publication addresses, online journals, or material sources including http://asian-efljournal.com/teaching-articles/, $\quad$ http://americanenglish.state.gov/englishteaching-forum.

From the data collected, the researcher obtains the ones on the expectations of students. The lecturer presents his/her own scientific journal in class so that students are more motivated in making scientific writing. The work of lecturers can also be used as one of the examples included in the reference list of scientific works. Possible positive values from this activity include the possibility of the work of the lecturer to be cited so that it has more benefits, compared to if it only ends in a research report or proceedings after joining a conference or scientific seminar with colleagues.

In line with the idea above, lecturers can compile the work of EED lecturers. Multiple benefits can be obtained because of it. First, institutionally, the EES has documentation of lecturers' articles. Another benefit is to make it easier for students to obtain examples from their own lecturers' work. 
Besides using the articles for the studnts in the class, lecturers can use the articles publised to socialize their work. For example, a paper that has been created or presented at a seminar or conference forum can be put together or published in online media. Technological advances now allow lecturers to upload their scientific work on the official website of the university or departments (such as: eprint.uad.ac.id, pbi.uad.ac.id, journal.uad.ac.id) or other pages (such as: www.academia.edu, or the teacher / lecturer forum on Facebook, on Google Scholar etc.)

Selection of other sources (which are audio and video) below textbooks / modules, sources from the Internet, and journal articles more or less reflects views of students about writing activities that are still separated from other skills. The integration of material delivery of writing skills with other language skills (listening, speaking, reading) seems not yet a discourse to deal. The application of Academic Writing through elearning (mean $=3.660$ ) has not been a priority for the students.

To initiate the implementation of integrated English teaching, lecturers can take advantage of short talk in academic forums in the Academic Writing class. Audio sources such as the TOEFL test or audio visual sources from www.youtube.com or even from seminar in the EED itself can be utilized.

This periode of time the focus of students in writing Academic Writing is related to the 3 main problems. In writing scientific works, EED students find difficulties in developing ideas, use of grammar, vocabulary and expression of language and efforts to motivate themselves. The students propose to hold journal writing as a means for reflection from the Academic Writing class and the preparation of portfolios to show the progress achieved in Academic Writing.

Regarding difficulties in developing ideas, several activities in Academic Writing classes can be undertaken. In the planning stage, Seow (2002), among others, offers the need for group brainstorming, Wh-questions on a topic, sources of multimedia and interviews, questionnaires and frequently asked questions about ideas to be written. Another possibility is to invite students to individually or in groups do mind mapping so that supporting ideas can be organized to produce scientific writing. At the initial stage, training in the form of collaborative writing can be applied.

For English grammar in Academic Writing, lecturers need to realize that this course is not a grammar subject. Thus, improving student grammar should not be an activity that dominates the class. Grammar points that are considered important can be inserted in the learning process. Different aspects of grammar can be classified so that Academic Writing students get clarity in an effort to improve the quality of their writing.

Gulcat and Ozagac (2004) state there are 10 biggest problems for Turkish learners in writing English as a second language. The first five are the use of articles, prepositions, infinitives, types of words (nouns, adverbs, adjectives ), suitability in the subject and verbs, pronoun and tense. While the other five 
problems are choosing the right tense and form, active-passive voices, sentence structures (fragments, run-ons, convoluted sentences), punctuation and style in writing can be better with a lot of writing experience in the language studied.

This explanation is similar to what happened in EED. The lack of fulfillment of minimum requirements in Academic Writing can be used as a basis for improving the quality of student writing. Concord between subject and verb, use of articles and use of singular and plural noun forms are still the material for students to revise their writings. In fact, those details on grammar mentioned are not covered in focus of this recent research. Further investigation is demanded, especially, the one related to Academic Writing.

What needs to be considered next is a strategy to overcome these problems in the Academic Writing. Does the lecturer need to provide special time for grammar or is it enough to convey it implicitly as suggestions generally in the Academic Writing class? Models such as 'matriculation' might be applied, by delivering supporting grammar materials for developing the ability to write scientifically by providing simple handbooks as a first step before students focus on writing the contents of their scientific work.

Given the complexity of the problems in Academic Writing, aspects of student motivation still need attention. Giving too many suggestions to all aspects that have already been discussed will reduce student enthusiasm in learning. Feedback is given as needed and there should be clarity of expected improvement. Clear and constructive comments will support efforts to improve writing quality while verbal and written appreciation from lecturers will also affect the psychological and mental side of students in an effort to improve academic writing skills. In addition, internal policies to send student scientific work to scientific forums can be considered as an effort to increase student motivation in Academic writing.

\section{CONCLUSION}

The research describing students' needs for English Education Department (EED) for Academic Writing courses reveals what is considered important / interesting by students, including materials, learning activities, skills and sources of Academic Writing. Students expects that lecturers are more active in scientific work and in assisting students in Academic Writing classes to overcome their problems in Academic Writing through active learning. The results of this study can be used as a starting point for developing Academic Writing materials in EED.

This study can lead to multiple effects such as giving a real contribution to the preparation of the procurement of learning material in the English Education Department of FKIP UAD. In addition, the results obtained support the efforts of lecturers to pay attention to suggestions from the students and related parties in preparing and providing teaching materials. Also, exploration of the needs of students in Academic Writing can provide suggestions for the department for material review of teaching and learning activities, material or even implementable curriculum. 


\section{REFERENCES}

Alvarez, D. (2007). A concert of voices: Helping college-level ESL students learn to write research paper. Master's thesis. Seattle, W.A.: The University of North Carolina at Charlotte. Retrieved from http://www.tesol.org/docs/pdf/8103.PDF

Bailey, S. (2003). Academic writing. New York: Nelson Thornes.

Brown, J.D. (1995). The elements of language curriculum. Boston: Heinle \& Heinle Publishers.

Dudeney, G. dan N. Hockly. (2007). How to teach English with technology. Essex: Pearson Education Limited.

Fatimah, N. (2012). Pengembangan materi kuliah English for children berbasis project work. Yogyakarta: Laporan Penelitian LPP UAD

Gulcat \& Ozagac. (2004). Correcting and giving feedback to writing. Accessed from

http://www.buowl.boun.edu.tr/teachers/CORRECTING\%20AND\%20G IVING\%20FEEDBACK\%20TO\%20WRITING.pdf

Hutchinson, T. \& A. Waters. (1986). English for specific purposes. Oxford: Oxford University Press.

Hyland, K. (2003). Second language writing. Cambridge: Cambrige University Press.

Luong Quynh Trang, \& Nguyen Thi Mai Hoa. (2008). Student writing process, perceptions, problems, and strategies in writing academic essays in a second language: A case study. VNU Journal of Science, Foreign Languages. 24. 2008. pp. 184-197. Accessed from http://tapchi.vnu.edu.vn/3_208_NN/6.pdf

Murray, D.E. and M.A. Christison. (2011). What English language teachers need to know, Volume II: Facilitating Learning, New York: Roudledge.

Myles. J. (2002). Second language writing and research: The writing process and error analysis in student texts. In TESL-EJ 6 (2) September 2002, pp. 1-20. Accessed from http://www.cc.kyoto-su.ac.jp/information/teslej/ej22/a1.html

Nurohman, Sabar. (2011). Pengembangan modul elektronik berbahasa Inggris menggunakan ADDIE-model sebagai alat bantu pembelajaran berbasis 
student-centered learning pada kelas bertaraf internasional. Prosiding Seminar Nasional Penelitian, Pendidikan dan Penerapan MIPA. Yogyakarta: UNY.

Paquot, M. (2010). Academic vocabulary in learner writing: From extraction to analysis. London: Continuum International Publishing Group.

Raimes, A. (2002). Ten steps in planning a writing course and training teachers of writing. In Richards and Renandya's (Eds.) Methodology in Language Teaching. Cambridge: Cambridge University Press.

Seow. (2002). The writing process and process writing. In Richards and Renandya's (Eds.) Methodology in Language Teaching. Cambridge: Cambridge University Press.

Setiawan, D. (2009). Investigating the perceived needs of international students learning EAP. TEFLIN Journal, 20(1), February 2009, pp. 48 - 60.

Taylor, G. (2009). A student's writing guide. Cambridge: Cambridge University Press.

Tomlinson, B. (1998). Materials development in language teaching. Melbourne: CUP.

Thais, Christ, dan Terry Zawacki. (2006). Engaged writers, dynamic disciplines: Research on the academic writing life. Portsmouth, $\mathrm{NH}$ : Boynton/ Cook, Heinnemann. In http://classweb.gmu.edu/bhawk/302/academic.pdf

Ybarra, R. \& T.Green. (2003). Using technology to help ESL/EFL students develop language skills. The Internet TESL Journal, IX, No. 3, March 2003. Retrieved from http://iteslj.org/Articles/Ybarra-Technology.html 